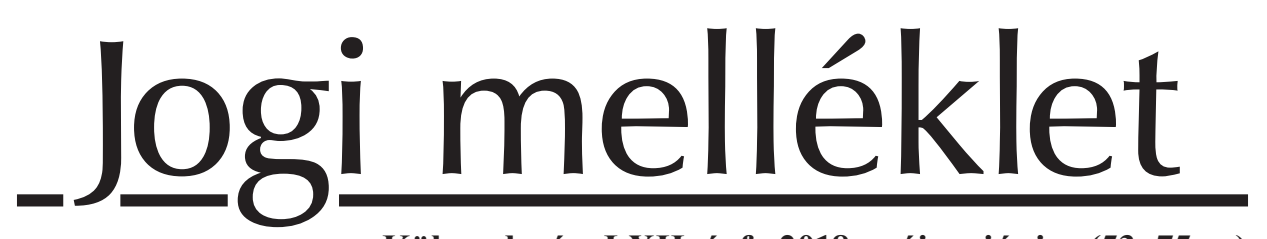

Külgazdaság, LXII. évf., 2018. május-június (53-75. o.)

\title{
A magyar ,máltai eset", cirkuszi artisták, büvészek és részvények: régi ügyek az új nemzetközi magánjogi törvény egyes általános részi szabályainak kodifikációja apropóján SZABÓ SAROLTA
}

Az Országgyülés 2017. április 4-én fogadta el és 2018. január 1-jétől lépett hatályba a 2017. évi XXVIII. törvény a nemzetközi magánjogról (a továbbiakban: új Kódex), ${ }^{1}$ amely célja szerint a korábbi 1979. évi 13. tvr. (a továbbiakban: régi Kódex)² szabályait modernizálja és finomítja. ${ }^{3}$ Jelen tanulmányban a régi Kódex bírósági gyakorlatában felmerült olyan jogesetek kerülnek bemutatásra és elemzésre, ${ }^{4}$ amelyek - a szerzö reményei szerint - nemcsak képet adnak az általános részi jogintézmények - néha igencsak összetett - müködéséröl, hanem amelyek megvilágítják az új Kódex egyes változtatásainak indokát is.

Journal of Economic Literature (JEL) kód: K1 Basic Areas of Law, K19 Other.

\section{Bevezetés}

A téma indokoltságát az adja, hogy mint látni fogjuk, az általános részi jogintézmények funkciójának ismerete az alkalmazandó jog kiválasztásának első lépése,

1 Kihirdetve a Magyar Közlöny 2017. évi 17. számában.

2 Kihirdetve a Magyar Közlöny 1979. évi 33. számában. Hatályba lépett 1979. július 1-jén.

3 A kezdetek: Vékás [2015], 295-299. o.

${ }^{4}$ A jogesetek tényállásai (és még több nemzetközi magánjoggal kapcsolatos ügy) megtalálhatóak: Szabó-Raffai-Vadász [2017].

Szabó Sarolta, egyetemi docens, Pázmány Péter Katolikus Egyetem Jog- és Államtudományi Kar, Nemzetközi Magánjogi Tanszék. E-mail: szabo.sarolta@jak.ppke.hu

https://doi.org/10.47630/KULG.2018.62.5-6.53 
amely alapvető hatással lehet az ügy érdemi elbírálására, végkimenetelére. Azért a jogesetek felől közelítjük ezt meg, mert igazából e területen különösen jelentős a bírósági gyakorlat szerepe. Ti. többségében „olyan módszertani kérdések tartoznak ide, amelyek nem alkalmasak arra, hogy behatóbb normatív szabályozás tárgyát képezzék. Nagy a veszélye annak, hogy a részletes törvényi szabályozás az ide sorolható jogintézményeket megmerevíti, ezáltal szükségtelenül megkötve a jogalkalmazó kezét." Az érem másik oldala ellenben, hogy mindenképpen szükségesnek mutatkozik a joggyakorlat orientálása is az összetettebb nemzetközi magánjogi eseteknél. ${ }^{6}$ Szükségesnek mutatkozik tehát az egyes - ritkább - esetek oldaláról bemutatni a régi és az új Kódex közötti eltéréseket e terület szabályozását illetően.

Az általános részben a régi Kódex az alábbi jogintézményekről rendelkezett: a minősítés, a vissza- és tovább utalás, a külföldi jog tartalmának megállapítása, a viszonosság, a közrendi záradék, a csalárd kapcsolás és a külföldi jog alkalmazásának felek kérelmére történő mellőzése. Az új Kódex a minősítés, a vissza- és tovább utalás, a külföldi jog tartalmának megállapítása, a közrendi záradék már korábban is rendezett jogintézményein túl szabályozza továbbá a több jogrendszerrel rendelkező államok (területközi és személyközi kollíziók), a jogválasztás, az általános kitérítő klauzula, az általános kisegítő szabály, a feltétlen alkalmazást kívánó szabályok (imperatív normák) és a statútumváltás kérdésköreit is. Nem rendezi azonban - a korábbiaktól eltérően - a viszonosságot, a csalárd kapcsolást és a felek közös mellözési kérelmét. ${ }^{7}$

A következőkben elsőként a minősítés kérdését járjuk körbe a tankönyvekben csak máltai esetnek hívott jogeset ${ }^{8}$ - ha úgy tetszik - hazai verziójával. Ezután a cirkuszi artisták házassági vagyonjogi jogvitája kapcsán egy igazán összetett ügyet elemzünk, amelyben a magyar bíróságnak a régi Kódex téves kapcsolása miatt az általános részi szabályokkal operálva kellett a ,jog igazságosságának”9 érvényt szereznie. Végül két esetben szemléltetjük, hogy miért volt szükség a régi Kódexben a külföldi jog tartalmának megállapításánál lévő normaszöveg kiegészítésére, valamint egyértelműsítésére.

${ }^{5}$ A svájci nemzetközi magánjogi törvényjavaslathoz készített szakértöi bizottsági jelentésének gondolatát idézi: Burián [2017], 3. o.

${ }^{6}$ Uo.

7 Ennek részletes indokairól: Burián [2017], 3-5. o.; Vékás [2016], 22-28. o. A törvényröl lásd még: Raffai [2017], 53-67. o.

${ }^{8}$ Burián-Czigler-Kecskés-Vörös [2010], 102. o.

9 Bővebben a jog, valamint az anyagi jogi-nemzetközi magánjogi igazságosság összefüggéseihez: Vékás [1986], 89-109. o. 
A magyar „máltai eset”, cirkuszi artisták, bủvészek és részvények: régi ügyek...

\section{Magyar „máltai eset”}

\section{II.1. A minősités és az eredeti máltai házassági eset}

A minősítés (qualification, classification) problematikája tulajdonképpen a kollíziós szabály tényállásaiban szereplő, absztrakt fogalmakként megjelenő anyagi jogi intézményeknek (pl. házassági vagyonjog, öröklés, szerződés, szerződésen kívüli károkozás) a különböző jogrendszerekben lévő tartalmi (elnevezésbeli, elhelyezésbeli) eltéréseiből ered. A nemzetközi magánjogban tehát minősítésnek nevezzük az adott tényállásra (tulajdonképpen a megválaszolandó jogkérdésre) illö kapcsoló szabály kiválasztását és az elbírálandó jogviszonyra történő alkalmazását. ${ }^{10} \mathrm{~A}$ magyar nemzetközi magánjogi szabályok nyilvánvalóan a hazai jogintézményekkel és jogi fogalmakkal dolgoznak. Viszont mivel nemzetközi magánjogi ügyekben több jog ütközéséröl, kollíziójáról beszélünk, így (legalább egy) másik állam jogának szabályai is alkalmazást kívánnak maguknak. A fő kérdés tehát, hogy melyik állam joga alapján értelmezzük a konkrét ügyben megválaszolandó jogkérdést.

A szakirodalom a minősítés problematikáját a XIX. században ismerte fel, a híres máltai házassági vagy Bartholo-esetben. A rövid tényállás szerint Marie Aquilina és François Bartholo Máltán éltek és ott kötöttek házasságot, majd átköltöztek Algírba, ahol akkor - francia gyarmatként - a francia jog érvényesült. A férj Algériában hunyt el. A francia fórum elötti vita tárgyát az algíri ingatlanhagyaték képezte, amelynek egy részére az özvegy igényt tartott, ún. özvegyi negyedet kért. Ezt a jogintézményt azonban csak a máltai jog ismerte, a francia nem. Minősíteni kellett tehát a megválaszolandó jogkérdést. Amennyiben az özvegyi negyedet öröklési jogi kérdésnek tekintjük, akkor azt a francia kollíziós szabályok szerint az ingatlan fekvési helyének joga, azaz a francia jog rendezné, amely azonban nem ismeri az özvegyi negyed jogintézményét, tehát az özvegy helyett a francia államra háramlana a vagyon. Az özvegy viszont arra hivatkozott, miszerint az özvegyi negyed nem öröklési jogi, hanem házassági vagyonjogi intézmény, tehát a francia nemzetközi magánjog házassági vagyonjogra vonatkozó kollíziós kapcsoló szabályát kell alkalmazni. E szerint a házastársak első közös lakóhelyének jogát kell alkalmazni, ${ }^{11}$ amely Máltán

${ }^{10}$ Burián-Raffai-Szabó [2017], 157. o.; Mádl-Vékás [2012], 103. o.; Burián-Czigler-KecskésVörös [2010], 103-105. o.

${ }^{11}$ A kapcsolószabály a sok vallást kipróbált, de halálos ágyán rekatolizált Charles Dumoulintől (más néven Carolus Molinaeus) származik. 
volt, a máltai jog pedig ismeri az özvegyi negyedet, tehát az özvegy örököl. A Cour d'appel d'Alger 1889. december 24-i ítéletében az esetet házassági vagyonjogi ügyként minősítette, így az özvegy hozzájutott a peresített vagyonhoz.

\section{II.2. A magyar „máltai eset” tényállása és birósági itéleteinek rövid összefoglalója}

A Fővárosi Ítélőtábla 2013-ban meghozott, nemzetközi magánjogi aspektusból kiválóan indokolt és világosan levezett döntése hasonló kérdést vet fel, mint a máltai eset csak - mondhatni - modernebb tényállással és a francia mellett magyar (német és amerikai) elemekkel. ${ }^{12}$

A magyar és amerikai kettős állampolgár örökhagyó és francia állampolgár felesége (felperes) 1964-ben Franciaország New York-i konzulátusán kötöttek házasságot, majd Párizsba költöztek. Házassági vagyonjogi szerződésük szerint vagyonukat elkülönülten kezelik, a házasság közöttük vagyonközösséget nem teremt. Az örökhagyó 1966-ban szerezte meg egy budapesti öröklakás (perbeli ingatlan) tulajdonjogát. Az örökhagyó későbbi élettársával (alperes) 1971-ben ismerkedett meg, akivel bár 1974-től Münchenben éltek együtt, azonban a felperessel a házassági életközösséget és a felperessel közös párizsi lakását lakóhelyéül is fenntartotta. Az örökhagyó 1978-ban kelt írásbeli magánvégrendeletében az állt, hogy németországi és magyarországi vagyonát az alperes örökölje. A házastársak 1987-ben Párizsban, közjegyzői okiratba foglalt szerződéssel vagyonelkülönítő rendszerüket megváltoztatva a francia Ptk. (a továbbiakban: Code Civil) szerinti egyetemes vagyonközösségi rendszer alkalmazásában állapodtak meg. A felek érvényesen megállapodtak abban is, hogy egyikük halála esetén a vagyonközösséget alkotó valamennyi ingó és ingatlan javak tulajdonjoga a túlélö felet illeti meg, anélkül hogy az örökösök erre jogot formálhatnának, s amely javak így nem képezik a majdani örökhagyó hagyatékának részét.

Az örökhagyó 1999. szeptember 15-én Párizsban elhunyt, magyarországi hagyatékát a perbeli ingatlan képezte. A hagyatéki eljárásban az ingatlanra a felperes a házassági vagyonjogi szerződés, az alperes pedig a végrendelet alapján tartott igényt. A magyar közjegyző hagyatékátadó végzéssel a perbeli ingatlan tulajdonjogát megosztotta az alperes és a felperes között.

12 Fővárosi Ítélőtábla 1.Pf.20.214/2012/25. 
A magyar „máltai eset”, cirkuszi artisták, bủvészek és részvények: régi ügyek...

A felperes a végzéssel szemben a magyar bírósághoz fordult. Tulajdoni igényét a francia jog alapján kötött házassági vagyonjogi szerződésre alapította, az ingatlan kizárólagos tulajdonjogát követelve. Az alperes védekezésében a magyar jog alapján hivatkozott arra, hogy a halál esetére szóló rendelkezések az öröklési jog körébe tartoznak, ezáltal az örökhagyó magyarországi hagyatékára a magyar Ptk. rendelkezései az irányadók, amely alapján a házassági vagyonközösségi szerződésbe foglalt megállapodás érvénytelen.

Az elsőfokú bíróság a magyar Ptk. rendelkezései alapján a felperes keresetét elutasította, ti. az örökhagyó az alperes javára szóló végintézkedését nem vonta vissza, ezért az érvényes és hatályos.

Az Ítélőtábla érvelésében, észlelve a külföldi elemet, az akkor hatályos régi Kódex szabályaihoz fordult. Felismerte, hogy az elsőfokú bíróság a megválaszolandó jogkérdést nem minősítette, ezért a házassági vagyonjogi szerződést vette górcső alá. Mivel a magyar házassági vagyonjog a fent ismertetett, felperes és az örökhagyó megállapodása szerinti jogszerzés jogintézményét nem ismeri, az abból eredő igény minősítéséhez nem a magyar jogot (a régi Kódex 3. § (1) bekezdése), ${ }^{13}$ hanem a külföldi jogot vette figyelembe (a régi Kódex 3. § (2) bekezdése). ${ }^{14}$ Az İtélőtábla ezután felvilágosítást kért a vonatkozó francia jogi szabályokról (a régi Kódex 5. § (2) bekezdés szerint) ${ }_{1}^{15}$ amelynek beszerzését követően megállapította a következöket. A perbeli jogvita minősítése szempontjából lényeges, hogy a Code Civil 1524. szakasz és 1525. szakasz első bekezdéséből kitűnően egyetemes vagyonközösségi rendszer esetén a házastársak házassági szerződéssel nemcsak a házassági életközösség időtartamára, hanem a vagyonközösség egyik házastárs halálával bekövetkező megszünése esetére is rendezhetik a tulajdoni viszonyokat, melynek megengedett módja a közös vagyon egészére a túlélő házastárs tulajdonjogának kikötése. Mivel a teljes közös vagyon tulajdonlásának kikötése sem érdemben, sem formailag nem tekinthető adományozásnak, ebből szükségszerủen következik, hogy ez olyan sajátos házassági vagyonjogi jogintézmény, amellyel a házastársak a közös vagyonból őket illető rész tulajdonjoga átszállására irányuló rendelkezés nélkül állapodhatnak meg abban, hogy a közös vagyon egésze a túlélő házastárs tulajdona. Ennek megfelelően

13 „Ha az alkalmazandó jog meghatározása szempontjából a jogvitában megítélendő tények vagy viszonyok jogi minősítése kérdésében vita van, a magyar jog szabályainak és fogalmainak értelmezésével kell eljárni."

${ }^{14}$ „Ha a magyar jog valamely jogintézményt nem ismer, vagy eltérő tartalommal, más elnevezéssel ismer, és az a magyar jog szabályainak értelmezésével sem határozható meg, a jogi minősítésben a jogintézményt szabályozó külföldi jogra is figyelemmel kell lenni."

${ }^{15}$ „A külföldi jogról a bíróság vagy más hatóság megkeresésére az igazságügyért felelős miniszter felvilágosítást ad." 
a felperes és az örökhagyó házassági szerződése jelen ügyben nem végintézkedés. A bíróság verdiktje szerint tehát a közös vagyon nem tartozik az elhunyt házastárs hagyatékába, tekintettel arra is, hogy a házastársak szerződéssel való rendelkezése és a közös vagyonra vonatkozó végrendelkezés összeegyeztethetetlen jogügyletek.

Mindezek alapján a magyar fórum nem a fószabály, a magyar jog, hanem a kivételszabály, a külföldi, tehát a francia jog szerint minősítette a felperes igényét. Ennek alapján nem az öröklési, hanem a házassági vagyonjogi kapcsoló szabály sorolta be a jogviszonyt. Végül - közös személyes jog hiányában, mivel különböző állampolgárságokkal rendelkeztek - a házastársak utolsó közös lakóhelye alapján a kereset elbírálására a francia jogot kellett alkalmazni, ${ }^{16}$ mert az Párizsban volt. Az Ítélőtábla az elsőfokú bíróság ítéletét megváltoztatta, és megállapította, hogy a magyar ingatlannak a hagyatéki eljárásban alperes részére átadott része a felperes tulajdonát képezi. A felek által ugyanis a Code Civil 1526. szakasza szerinti egyetemes vagyonközösségi rendszerre alapított megállapodásának a) pontja szerint a vagyonközösségbe tartozik a házastársak ,,jelenleg” tulajdonában lévő teljes ingóés ingatlan vagyon, amit eddig bármely jogcímen szereztek. A magyar ingatlant az örökhagyó a szerződéskötést megelőzően, 1966-ban szerezte, így az közös vagyon.

\section{II.3. Esetelemzés a régi és az új Kódex összevetésével}

Könnyen észrevehető a párhuzam a máltai eset és annak hazai megjelenése között. Mindkét ügyben a fórum a saját joga helyett a külföldi jog jogintézményét, besorolását vette figyelembe a megfelelő (primer) minősítéshez. A máltai és a - mi szempontunkból mondjuk - francia házassági esetben is házassági vagyonjogi és nem öröklési kérdésnek minősítette az adott jogkérdést a francia és a magyar bíróság, és az annak megfelelő kapcsolószabály által kijelölt jogot alkalmazta, ezzel oldva fel a jogrendszerek ütközését.

Ahogy az a bevezetőben említésre került, az új Kódex kodifikációja során felmerült, hogy - az ítélkezési rugalmasságot biztosítandó - csak a legszükségesebb mértékig szabályozza a jogalkotó az általános rész - néha amúgy is - nehezen definiálható jogintézményeit. Ráadásul a minősítés problematikájának összetettsége miatt a jogalkotók csak ritkán vállalkoznak a minősítés kérdésének normatív szabályozásá-

${ }^{16}$ A régi Kódex 39. § (2) bekezdése: „Ha a házastársak személyes joga az elbírálás idején különböző, utolsó közös személyes jogukat, ennek hiányában annak az államnak a jogát kell alkalmazni, amelynek területén a házastársaknak utoljára közös lakóhelyük volt.” 
A magyar „máltai eset”, cirkuszi artisták, büvészek és részvények: régi ügyek...

ra. ${ }^{17}$ Végül mégis, a kevés (sokszor a minősítés kérdését „kihagyó”) joggyakorlat és a judikatúra útba igazításának igényével került megalkotásra a minősítés - régi normaszöveghez képest - átírt, „finomított” normaszövege. Az új Kódexben a hatályt meghatározó rendelkezéseket és az értelmező szabályokat követő 4. § a „Minősítés” címet viseli. A szabály - a korábbi megoldást alapul véve - a tényállásra (elbírálandó jogkérdésre) alkalmazandó kollíziós szabály meghatározására a magyar jog (lex fori) fogalomrendszerét veszi irányadónak [4. § (1) bekezdés]. A (2) és (3) bekezdésben pedig - a régi Kódexszel ellentétben - szerkezetileg is elkülönítetten kínál megoldást arra a két leggyakoribb helyzetre, ha a magyar jog nem ismeri az adott jogkérdést, vagy ha a magyar jog ismeri, de a jogkérdés funkciója vagy célja eltér attól, amit a külföldi jogban betölt. Ez utóbbi két esetben a minősítés során a külföldi jogra is figyelemmel kell lenni. A funkcióra és a célra történő utalással a jogalkotó a funkcionális-teleologikus minősítést ajánlja a jogalkalmazó figyelmébe. ${ }^{18}$

\section{Cirkuszi artisták esete}

III.1. A cirkuszi artisták esetének tényállása

A Kúria - és az alsóbb fokú bíróságok - nemzetközi magánjogi értelemben egy igen összetett üggyel, mondhatni egy igazi „,kemény dióval” találták magukat szembe. A 2013-ban meghozott ítélet tényállása bár kalandosan, sok nemzetközi elemmel indul, de - sajnos - szokványosan végződik. ${ }^{19}$

A cirkuszi artistaként dolgozó felek, felperes magyar állampolgár, magyarországi lakóhellyel és az alperes brit állampolgár, dán lakóhellyel, 1987. április elején - pár hónapos ismeretség után - Dániában házasságot és házassági szerződést kötöttek. A felek a házassági szerződésben teljes vagyonelkülönítésben állapodtak meg és kizárták a közös vagyon keletkezésének minden formáját. Az okiratot a dán alaki előírásoknak megfelelő formában ügyvéd készítette el, $\mathrm{s}$ azt a dán jognak megfelelően, a Koppenhágai Helyi Bíróság által vezetett nyilvántartásba be is jegyezték.

Az életközösség 16 év után megszakadt, és a házasságot végül 2009. április 28. napjával a német bíróság bontotta fel, mert ekkor a felek közös lakóhelye már Né-

17 Vékás [2016], 19. o.

${ }_{18}$ Burián [2017], 7. o.

${ }^{19}$ Kúria Pfv. II. 21. 678/2012.; Kúria BH 2014.1.26. 
metországban volt. Ezt követően a volt feleség az ismételten megváltozott lakhelye szerinti magyar bírósághoz fordult, és kérte a házassági vagyonjogi szerződés érvénytelenségének megállapítását arra hivatkozva, hogy a házassági szerződésre a magyar kollíziós szabályok szerint alkalmazandó német Ptk. (Bürgerliches Gesetzbuch - a továbbiakban: BGB) elöírásai alapján a Dániában kötött szerződés alaki okokból semmis.

Az alperes a kereset elutasítását kérte. Vitatta ugyanis, hogy a szerződés alaki érvényességét a német jog alapján kell elbírálni.

\section{III.2. Az elsőfokú biróság itélete}

Az elsőfokú bíróság ítéletével a felperes keresetét elutasította. A döntését azzal indokolta, hogy az alkalmazandó jog tekintetében a régi Kódex vonatkozó szabályai szerint a házastársak személyi és vagyoni jogviszonyaira - ideértve a házassági vagyonjogi megállapodást is - az a jog az irányadó, amely az elbírálás idején a házastársak közös személyes joga. Ennek hiányában utolsó közös személyes jogukat, közös személyes jog hiányában pedig annak az államnak a jogát kell alkalmazni, amelynek területén a házastársaknak utoljára közös lakóhelyük volt [régi Kódex 39. § (2) bekezdés]. A tényállás alapján a feleknek közös személyes joga soha nem volt, így a jogvitában a magyar kollíziós szabályok szerint alkalmazandó jog a házastársak utolsó közös lakóhelye szerinti német jog. A BGB törvényes házassági vagyonjogi rendszere, az ún. szerzeményi közösség (Zugewinngemeinschaft - „nyereségközösség”) szabályai alapján az alperesnek a saját vagyongyarapodásának a reá eső fele részét kellett volna megtérítse a felperesnek. ${ }^{20} \mathrm{~A}$ német jog szerint ettől azonban a felek szerződéssel eltérhetnek, azonban a házassági szerződés alaki érvényességének feltétele, hogy az egyidejüleg jelenlévő felek megállapodásukat közjegyzői okiratba foglalják. Az alaki kötöttségek megsértésével kötött szerződés semmis. ${ }^{21}$

Az elsőfokú bíróság szerint azonban nem a német anyagi jog kerül alkalmazásra, mert a német nemzetközi magánjogi törvény (Einführungsgesetz zum Bürgerlichen Gesetzbuche - a továbbiakban: EGBGB) elfogadja a továbbutalás intézményét, így a külföldön kötött házassági szerződés alakiságát az EGBGB vonatkozó cikkei

20 BGB 1378-1379, 1410. §

21 BGB 125. $\S$ 
A magyar „máltai eset”, cirkuszi artisták, bủvészek és részvények: régi ügyek...

alapján a szerződéskötés helyének joga szerint kell elbírálni. ${ }^{22}$ Ennélfogva a házassági szerződés alaki érvényességére a dán jogot tekintette irányadónak, amelynek a szerződés alakilag megfelel. Az elsőfokú bíróság álláspontja szerint a fenti értelmezést erősíti a méltányosság és a jogbiztonság elvének érvényesüléséhez füződő alapvető érdek is.

\section{III.3. A másodfokú biróság itélete}

A másodfokú bíróság ítéletével az elsőfokú bíróság ítéletét helybenhagyta. Indoklásában rámutatott a felperes által is hivatkozott nemzetközi magánjogi jelenségre, az ún. forum shoppingra. Ti., amennyiben a felperes közvetlenül a német bíróság előtt indított volna eljárást, akkor az EGBGB alapján - a fenti utat bejárva, a 11. cikk utalására - a dán jog lett volna alkalmazandó, amely szerint a szerződés alakilag érvényes. A felperes azonban azért indította meg az eljárást a magyar bíróság elött, mert a régi Kódex főszabályként csak szűk értelemben fogta fel az utalást, azaz a felhívott jog közvetlen jogrendezést biztosító (anyagi) szabályait kellett alkalmazni, kivéve a visszautalás esetét (régi Kódex 4. §). Mivel az EGBGB 11. §-ában továbbutalt volna a dán jogra, de a továbbutalást a régi Kódex nem tette lehetővé, ezért a magyar bíróságnak a német házassági vagyonjogi szabályokat kellene alkalmazni. (A felperes tehát fórumot „vásárolt”.)

Ugyanakkor, tette hozzá az egyébként fenti helyes érveléshez egy csavarral a másodfokú bíróság, a régi Kódex a Kötelmi jogi részében külön szabályozza a szerződés alaki érvényességét, amelyet ezen kollíziós szabályok szerint a dán jog szerint kell elbírálni, de a magyar polgári anyagi jog szerint is vizsgálható. Mivel „a házassági vagyonjogi szerződés is a kötelem egy típusa, így erre a szerződésfajtára is alkalmazni kell - a Régi Kódex [régi Kódex] Családi jogról szóló VII. fejezetében speciálisan nem szabályozott kérdésekben - a Tvr. [régi Kódex] szerződéses kötelmi jogra vonatkozó, általános rendelkezéseit.” Eszerint: „ha a szerződés a szerződésre vonatkozó jog szerint alaki okból nem érvényes, a bíróság a szerződést érvényesnek tekinti, amennyiben az eljáró bíróság államának vagy annak az államnak a joga szerint érvényes, amelynek területén a szerződést kötötték" ${ }^{23} \mathrm{~A}$ felek szerződésének alaki érvényessége pedig a dán jog szerint aggálytalan.

${ }^{22}$ EGBGB 11. és 15. cikk (1) bekezdések.

${ }^{23}$ Régi Kódex 29. § (2) bekezdés. 
A felperes a Kúriához fordult felülvizsgálati kérelemmel. A Kúria verdiktje szerint a másodfokú bíróság jogerős ítéletének indokolása az alkalmazandó anyagi jog vonatkozásában részben téves, részben hiányos, illetve pontatlan, az abban foglalt érdemi döntés azonban helytálló.

A Kúria szerint a törvényes vagyonjogi rendszerre kizárólagosan, a törvényes vagyonjogi rendszertől házassági vagyonjogi szerződéssel való eltérés adott jogrendszer általi megengedhetőségének, a szerződés formai (alaki) érvényességének, lehetséges tartalmának és nyilvántartásba vétele szükségességének a mikénti megítélésére pedig elsődlegesen a régi Kódex Családi jogról szóló VII. fejezetének a Házastársak személyi és vagyoni viszonyaira vonatkozó speciális kollíziós szabályai, míg másodlagosan, a családjog által nem szabályozott kérdésekben kisegítő jelleggel a Kötelmi jogról szóló V. fejezetének a Szerződéses kötelmi jogviszonyokra vonatkozó kollíziós szabályai együttesen irányadók. Bár a házassági vagyonjogi szerződés formájára a régi Kódex 39. § (2) bekezdése alapján - a közös személyes jog hiánya folytán - a volt házasfelek utolsó közös lakóhelye szerinti - német jog, azon belül is, a BGB 1410. § házassági vagyonjogi szabálya irányadó. Azonban a törvény által elöírt forma hiányának a jogkövetkezményei kizárólag a BGB kötelmi jogi jognyilatkozatok formai hibájának a jogkövetkezményeiről rendelkező 125 . § szerint ítélhetők meg. A Kúria álláspontja szerint tehát alaptalanul érvelt kérelmében a felperes azzal, hogy a régi Kódex V. fejezet Kötelmi jogról szóló szabályainak a házassági vagyonjogi szerződésre való alkalmazhatóságát már önmagában is kizárná az, hogy az V. fejezet kizárólag speciális kötelmi jogi viszonyokra vonatkozó, nem pedig olyan általános elöírásokat tartalmaz, amelyeket a VI., VII. és VIII. fejezetben szabályozott öröklési, családjogi és munkajogi viszonyokra egyaránt alkalmazni kellene, a VII. fejezet családjogra vonatkozó szabályai pedig az V. fejezet alkalmazására nem adnak módot.

A Kúria álláspontja szerint tévesen hivatkozott a felperes arra is, hogy a régi Kódex kötelmi jogi szabályainak a perbeli szerződésre való alkalmazhatóságát kifejezetten kizárja az Kötelmi fejezet azon rendelkezése is, amely szerint a szerződésre megengedi a jogválasztást, mert a Családjogi fejezet rendelkezései a jogválasztást egyáltalán nem teszik lehetővé. A Kúria ítéletében kifejtette, hogy a régi Kódex családjogi szabályai ugyan valóban nem tartalmaznak a házassági vagyonjogi szerződésre irányadó jog felek általi megválasztásának a lehetőségére vonatkozó rendel- 
A magyar „máltai eset”, cirkuszi artisták, büvészek és részvények: régi ügyek...

kezést, ebből azonban nem következik az, hogy a Kötelmi fejezet más szabályai az ilyen típusú szerződésekre nem lennének alkalmazhatóak.

A régi Kódex Szerződéses kötelmi jogviszonyokra vonatkozó V. fejezet 28. §-a szerint a külön nem nevesített „egyéb” szerződésekre jogválasztás hiányában azt a jogot kell irányadónak tekinteni, amelyhez a szerződés - az adott szerződéses viszony lényeges elemei szerint - leginkább kapcsolódik. A 29. § (1) bekezdésének főszabálya értelmében ugyan a szerződés joga kiterjed a kötelmi jogviszony minden elemére, így a szerződés alaki érvényességére is, de a (2) bekezdésének a kisegítő szabálya kivételt létesít, így ha a szerződés a szerződésre vonatkozó jog szerint alaki okból nem érvényes, a bíróság a szerződést érvényesnek tekinti, amennyiben az eljáró bíróság államának vagy annak az államnak a joga szerint érvényes, amelynek területén kötötték, vagy ahol a célzott joghatásoknak be kell állniuk. A Kúria döntése szerint ennek az a következménye, hogy a magyar bíróságnak a perbeli szerződést érvényesnek kell tekintenie, mert az a magyar jog ${ }^{24}$ alapján ugyan nem érvényes, azonban a szerződéskötés helye szerinti dán jog alaki érvényességi követelményeinek (írásba foglalás és bírósági nyilvántartásba vétel) megfelel.

A Kúria további indoklásában kifejtette: ,[...] a kontinentális jogrendszerekben a házassági vagyonjogi megállapodásokkal összefüggő jogviták érdemi elbírálása során a családjogi sajátosságoknak megfelelő többletgaranciák mellett az általános szerződési elveket, illetőleg a szerződések általános szabályait is megfelelően figyelembe kell venni.” Ennélfogva „a szerződések általános jogelveivel, nevezetesen a szerződésekbe vetett bizalom elvével, valamint a forgalombiztonság és kiszámíthatóság elvével is ellenkeznék az, hogy a több mint húsz évvel a szerződés megkötése és öt évvel az életközösség, illetőleg a szerződés hatályának megszűnése után elöterjesztett kereset alapján a felperes a dán jog alapján kikötött, de a német jog szerint is kiköthető vagyonelkülönítési rendszer helyett kizárólag a »forum shopping" elvére és az Nmjtvr. [régi Kódex] - továbbutalás lehetőségét kizáró - 4. §-ra alapítottan visszamenőleg érvényesíthessen az utolsó közös lakóhely törvényes vagyonjogi rendszere alapján a »Zugewinn« (nyereség, közszerzemény) elszámolására irányuló igényt az alperessel szemben."

„Éppen ez az oka azoknak a nemzetközi magánjogi törekvéseknek, amelyek - a forum shopping elvével szemben - az ún. nemzetközi magánjogi igazságosság elve alapján az alkalmazandó jogrendszer elöreláthatóságának biztosítására, a tényálláscsoportra legmegfelelőbb jog kiválasztására és a döntések nemzetközi harmóniájá-

${ }^{24}$ A házasságról, a családról és a gyámságról szóló 1952. évi IV. törvény (a továbbiakban: Csjt.) 27. § (3) bekezdése. 
nak biztosítására irányulnak. Ezt a célt szolgálja - többek között - a Régi Kódex 39. § (4) bekezdésének - a jelen perben nem alkalmazható - családjogi szabálya, amely szerint a házastársak személyes jogának megváltozása nem érinti a korábbi jog alapján megállapított névviselést, továbbá az érvényesen létrejött vagyonjogi hatásokat, ideértve a házassági vagyonjogi megállapodást is. A régi Kódex 29. § (2) bekezdése ugyanakkor - az elsőfokú bíróság által hivatkozott - locus regit actum elvének a szerződés alaki érvényességének elbírálása körében történő alkalmazása útján bizonyos fokú védelemben részesíti a szerződés alapján megszerzett jogokat akkor is, ha a szerződésre eredetileg irányadó jog nem a felek közös személyes jogának, hanem a felperes lakóhelyének az egyoldalú megváltoztatása folytán módosult."

III.5. Esetelemzés a régi és az új Kódex összevetésével

A fentebbiekben bemutatott eset kiválóan szemlélteti a kollíziósjog-kapcsolás nem megfelelő voltát. ${ }^{25}$ Tulajdonképpen mindhárom bíróságnak szembesülnie kellett azzal, amit Mádl Ferenc akként fogalmaz meg, hogy ,az ütközések véletlen variációinak nagy száma és esetleges jellege" váratlan jogrendszerek anyagi jogának alkalmazásához és jogi megoldásokhoz vezethet, ${ }^{26}$ amely tehát, mint láttuk, a régi Kódex alapvetően jogbiztonságra való törekvése esetén is előfordulhat. A hibalehetőségeknél a Vékás Lajos által említettek között, jelen ügyben, a kapcsolószabály diszpozíciójának helytelen megválasztásáról van szó. Ti., a régi Kódex nem tartalmazott külön (alternatív) kapcsoló szabályt a házassági vagyonjogi szerződések alaki érvényessége tekintetében. Az új Kódex, orvosolva a problémát, kisegítő rendelkezéssel kimondja, hogy a házassági vagyonjogi szerződés alaki szempontból érvényes akkor is, ha megfelel a megkötésének helye szerinti jognak (29. §).

Az esetben természetesen általános részi kérdések is felhívhatók, amelyek elemzéséhez a régi és az új Kódex rendelkezéseit szem előtt tartva a következő régen és újonnan kodifikált jogintézményeket vegyük alapul:

a) vissza- és továbbutalás (renvoi)

b) minősítés

c) általános kitérítő klauzula

d) statútumváltás.

${ }^{25}$ Vékás [1986], 95. o.

${ }^{26}$ Mádl [1987], 358. o. 
A magyar „máltai eset”, cirkuszi artisták, bủvészek és részvények: régi ügyek...

a) Vissza- és továbbutalás (renvoi)

A magyar bíróságoknak az ügyet, a nemzetközi elemre figyelemmel, a régi Kódex szabályai szerint kellett tehát elbírálnia. A joghatósága megállapítása után a házassági szerződésre alkalmazandó jogot kellett meghatározni. Mind a másodfokú bíróság, mind a Kúria helyesen jutott arra a következtetésre, hogy a régi Kódex házastársak személyi és vagyoni viszonyait szabályozó normája szerinti a közös lakóhely kapcsoló szabálya alapján [39. § (2) bekezdés] a magyar kollíziós szabály a német jogra utalt. Az EGBGB ugyan továbbutalt volna a dán jogra, de a magyar bírónak a magyar Kódex általános részének rendelkezéseit, azaz nem az EGBGB vissza- és továbbutalásra vonatkozó rendelkezését, hanem a saját, azaz az ügyben a régi Kódex 4. §-ának szabályait kellett alkalmaznia. Eszerint az alkalmazandó külföldi jognak a felmerült kérdést közvetlenül rendező szabályai irányadók, kivéve ha a felhívott jog kollíziós szabálya visszautal a magyar jogra. Jelen ügyben azonban az EGBGB a dán jogra utalt volna, amely továbbutalást a régi Kódex nem tette lehetővé. Ennek alapján tehát az ügyet a házastársak utolsó közös lakóhelye szerinti, német anyagi jog alapján kellett volna elbírálni, amely szerint a házassági vagyonjogi megállapodás alaki okokból érvénytelen. ${ }^{27}$

Az új Kódexben a jogalkotó a régi Kódex kompromisszumként született, ${ }^{28} \mathrm{fe}$ lemás és a továbbutalás kizárása miatt, a hazafelé törekvés eszközeként tekinthető renvoi szabályát megváltoztatta. ${ }^{29} \mathrm{Az} 5$. §-ban a következöképpen rendelkezik:

(1) Ha e törvénynek az alkalmazandó jogot meghatározó kolliziós szabályai külföldi jogra utalnak, a külföldi jognak a kérdést közvetlenül rendezö anyagi jogi szabályait kell alkalmazni.

(2) Ha az alkalmazandó külföldi jogot e törvény értelmében az állampolgárság határozza meg és a külföldi jog kolliziós szabálya

a) a magyar jogra utal vissza, a magyar anyagi jogot kell alkalmazni;

b) egy másik külföldi jogra utal tovább, ennek a jognak az anyagi jogi szabályait kell alkalmazni

A főszabály tehát továbbra is a vissza- és továbbutalás kizárása maradt, mégis jelentős változás a korábbiakhoz képest, hogy a visszautalást és a továbbutalást azonos feltételek mellett lehet megtenni. Visszautalás csupán azon jogviszonyokban

27 A magyar bíróságok felvetették, hogy a német bíró a német szabályok alapján - kiterjesztő értelmezéssel - akár érvényesnek is találhatta volna

${ }^{28}$ Mádl [1980], 250-284. o.

${ }^{29}$ Burián [2016], 31-43. o. 
megengedett, amelyekben az új Kódex szerinti állampolgárság kapcsoló szabálya következtében alkalmazandó külföldi jog kollíziós szabálya a magyar jogra visszautal. Továbbutalni pedig szintén csak akkor, ha az állampolgárság kapcsoló szabálya következtében alkalmazandó külföldi jog kollíziós szabálya egy másik külföldi jogra utal tovább. A továbbutalás lehetősége egyszeres, tehát az már anyagi jogra történő utalásként értelmezendő (onnan már nincs tovább- vagy visszautalás).

Jelen ügyben, mivel nem volt közös állampolgárságuk a feleknek, ez az új szabály nem változtatott volna a bíróságok dilemmáján, hiszen az utalás a német jogra megtörténne.

b) Minősítés

A másodfokú ítélet és a Kúria indokolása is a helyzetet - ugyan sajnos kimondatlanul - a minősítés jogintézményével oldotta meg. A perbeli jogkérdés, a házassági vagyonjogi szerződés alaki érvényességének rendszertani besorolása és a megfelelő kapcsoló elv alá vonása volt a minősítési feladat. Mint azt az elsőnek elemzett esetben is láthattuk, a minősítés megítélésére a régi és az új Kódex is föszabályként a lex forit rendeli. (Tekintettel arra, hogy az adott jogintézményt a magyar jog ismeri, és az céljában és funkciójában is azonos a külföldi jogokkal, a többi bekezdést nem kell elővegyük.) Amennyiben a magyar anyagi jogot nézzük, vegyes a kép. A házastársak vagyoni viszonyaira az akkor hatályos Csjt. IV. fejezetének „A házassági vagyonjog” címü 2. pontja alkalmazandó, amely kifejezetten rögzíti a törvényes vagyonjogi rendszertől való szerződéses eltérés lehetőségét, valamint a házassági vagyonjogi szerződés speciális alakiságait és tartalmi elemeit [27. § (2)(4) bekezdés]. Azonban a 31. § (5) bekezdése kimondta, hogy „,a házastársak közötti vagyoni viszonyokra (házassági vagyonjogi szerződés [...] stb.) a Ptk. rendelkezéseit is megfelelően alkalmazni kell". A kollíziós szabályok is a családjogi fejezetben említik a házassági vagyonjogi megállapodást, viszont az alakiságokat speciálisan ott nem rendezik. Annak a minősítési kérdésnek a megítélése, hogy a házassági vagyonjogi szerződés alaki érvényessége a családi jogba vagy a kötelmi jogba tartozó kérdés, összességében egyáltalán nem egyértelmű, és ebben a régi Kódex indokolása sem ad konkrét támpontot. Bár nézetünk szerint - végeredményében egyet értve és megértve a bíróságok szempontjait, a családjogba tartozónak tekintenénk a kérdést. Mindenképpen szerencsésebb tehát az új Kódex világosan megfogalmazott külön szabálya, amely a minősítési polémiát kioltja, pontosabban így fel sem veti. 
A magyar „máltai eset”, cirkuszi artisták, bủvészek és részvények: régi ügyek...

E kivételszabály - mint fentebb láttuk - ugyanis egyértelmüen a dán jogra mutat, amely szerint a felek szerződése alakilag érvényes.

c) Általános kitérítő klauzula

A modernitás és a rugalmasság biztosítása jegyében merült fel a Kodifikációs Bizottság ülésein az általános kitérítő klauzula (general escape clause, Ausweichklausel) beépítésének igénye az új Kódexbe. Ez a jogintézmény elsőként a svájci nemzetközi magánjogi törvényben jelent meg, ${ }^{30}$ majd sorra más külföldi, nemzetközi magánjogi joganyagban is kodifikálásra került. ${ }^{31}$ A jogintézmény célja, hogy korrigálja a nemzetközi magánjogi szabályok téves kapcsolását, azaz azt a helyzetet, ha a tényállás és az alkalmazandó jog még sincs eléggé szoros kapcsolatban egymással, ti. egy harmadik állam jogával az adott jogviszony szorosabb kapcsolatot mutat. Tehát a bíró mérlegelése alapján kivételes esetben (!) lehetőséget kap a korrekcióra, amennyiben a tényállás a Kódex kollíziós normája által kijelölt jog helyett egy másik joghoz lényegesen szorosabban kapcsolódik.

Az általános kitérítő klauzuláról az új Kódex 10. §-a következőképpen rendelkezik: „Ha az ügy körülményei alapján nyilvánvaló, hogy az ügy az e törvény szerint irányadó jognál lényegesen szorosabban kapcsolódik egy másik joghoz, kivételesen ezt a másik jogot lehet alkalmazni." Visszatérve az cirkuszi artisták esetére, az általános kitérítő klauzula megléte nyilvánvalóan megfelelö orvoslást jelenthetett volna a hasonló helyzetekre (ha a kollíziós normák „,vakok”). Kétségeket ébreszt viszont az új Kódex második mondata, amely igencsak meglepő és nemzetközi összehasonlításban is - finoman szólva - szokatlan módon időbeli korlátot szab a jogalkalmazónak az általános kitérítő klauzula alkalmazására. Ezen nóvum szerint: „, A bíróság erről az alperesi ellenkérelem birósághoz érkezésétöl számitott legkésőbb harminc napon belül dönteni köteles.” A Kodifikációs Bizottsági ülés anyagaiban nem szereplő határidő, amely elsőként csak a parlamentnek benyújtott törvényjavaslat szövegében bukkan fel, egy - talán az egyszerübb megítélésü ügyek kivételével - kivitelezhetetlen határidőt tűz a jogalkalmazónak, akitől elvárja, hogy egy nemzetközi magánjogi ügyben (amelyek általában komplikáltak) a fórum már azután harminc nappal tudja, hogy mi lesz az alkalmazandó jog és hogy az nem a legszorosabb kapcsolatot mutatja

${ }^{30}$ Burián [2017], 20-21. o.; Vékás [2016], 29. o.

${ }^{31}$ Pl. a belga (19. Cikk), holland (10:8. Cikk), litván (1.11. Cikk) és szlovén (2. Cikk) nemzetközi magánjogi rendelkezés. 
a tényállással, hogy felperes keresetlevelére az ellenkérelem beérkezett (rendszerint a perfelvételi szak előtt). Nem tudni, hogy mi volt ezzel az indokolatlan restrikcióval a cél, de annyi bizonyos, hogy a szabály ezzel a lényegét veszítette el. ${ }^{32}$

d) Statútumváltás

A régi Kódex nem tartalmazott általános rendelkezést a statútumváltásra, azokra az esetekre tehát, amikor az alkalmazandó jog egy jogviszony fennállása alatt valamilyen, a kapcsolás szempontjából releváns körülmény módosulása miatt megváltozik. A különös részben viszont néhány helyütt szólt a statútumváltásról, így a 39. § (4) bekezdésében is. Eszerint: „A házastársak személyes jogának megváltozása nem érinti a korábbi jog alapján megállapított névviselést, továbbá az érvényesen létrejött vagyonjogi hatásokat, ideértve a házassági vagyonjogi megállapodást is." Mivel a cirkuszi artisták esetében, bár statútumváltásról volt szó, de a jogszabályhely szerint a felek személyes joga (állampolgársága) nem változott, ezért az nem volt alkalmazható.

Az új Kódex vívmánya, hogy az egyszerüsítés igényével a statútumváltásról az általános szabályok között, a 12. §-ban rendelkezik. Nevesül: „Az alkalmazandó jogot meghatározó körülmények megváltozásának a változást megelözöen alkalmazandó jog szerint érvényesen létrejött jogviszonyokra csak akkor van hatása, ha e törvény kifejezetten így rendelkezik.” Ez is megfelelő eszköz lehetett volna az ügyben.

\section{Büvészek és részvények esetei: a külföldi jog tartalmának megállapítása}

A következő mindkét alábbiakban röviden bemutatott ügy a külföldi jog tartalma megállapításának folyamatára, nehézségeire és az új Kódex fogalmazásának „miértjeire” hívja fel a figyelmet.

32 Hasonló megállapításra jut: Burián [2017], 20. o. Nagy [2017], 44. o. 
A magyar „máltai eset”, cirkuszi artisták, bủvészek és részvények: régi ügyek...

IV.1. Karalyos és Huber kontra Magyarország és Görögország ügy

Az Emberi Jogok Európai Bíróságáig jutott a magyar büvészek deliktuális felelösségi esete. A Karalyos és Huber kontra Magyarország és Görögország ügy ${ }^{33}$ tényállása szerint Karalyos Csaba bủvész, Huber Kármen a partnere, magyar állampolgárok és budapesti lakosok 1994. március 1-jén szerződést kötöttek az „E Cruise Lines" nevü görög társasággal arra vonatkozóan, hogy a Pallas Athene nevü hajón nyolc hónapon keresztül előadják show-műsorukat. A görög társaság a Pallas Athene fedélzetén szállította az előadók felszerelését, amely 1994. március 24-én egy tüzvészben megsemmisült. Mivel a görög társaság nem volt hajlandó kártérítést fizetni, Karalyos és Huber 1995. január 25-én kártérítés iránti pert indított a görög társaság ellen a Pesti Központi Kerületi Bíróság (a továbbiakban: PKKB) előtt.

A régi Kódex szerint a deliktuális felelősségi kérdésekre főszabály szerint a károkozó magatartás helyének és idejének joga (lex loci delicti commissii) irányadó, kivéve, ha a károkozó tevékenység vagy mulasztás helye lajstromozott vízi vagy légi jármű, a károkozásra és annak következményeire - állami felségterületen kívül - annak az államnak a jogát kell alkalmazni, amelynek lobogója vagy más felségjelvénye alatt a jármủ a jogsértés idején közlekedett (lex bandi). Mivel a hajó görög lobogó alatt közlekedett, az alkalmazandó jog a görög volt. A bíróságnak tehát meg kellett ismernie a görög jog tartalmát. Ez az ,ismerkedés” kilenc évig tartott. A PKKB a magyar Igazságügyi Minisztériumon, a magyar pedig a görög Igazságügyi Minisztériumon keresztül próbálta beszerezni a görög jog tartalmát, de az nem sikerült, úgy is mondhatjuk, hogy a hatóságok „fogságába esett”. A PKKB hol nem volt elégedett a válasszal, hol nem kapott választ a görög hatóságoktól. A magyar Igazságügyi Minisztérium azt javasolta a PKKB-nak, hogy az elhúzódó folyamatra tekintettel a régi Kódex 5. § (3) bekezdése értelmében a görög törvény helyett a magyar törvényt alkalmazza. Azonban a PKKB arról tájékoztatta a magyar Igazságügyi Minisztériumot, hogy a görög joggal kapcsolatos tájékoztatásra szüksége van. Karalyos és Huber az Emberi Jogok Európai Bíróságához fordultak azt sérelmezve, hogy perük észszerűtlenül hosszú ideig elhúzódik, amely ellentétes az Egyezmény 6. cikkének (1) bekezdésével, amelynek deklarálja: „Mindenkinek joga van arra, hogy [...] bíróság [...] észszerủ időn belül [...] hozzon határozatot polgári jogi jogai és kötelezettségei tárgyában [...].”.

33 2004. április 6-i ítélet, Karalyos és Huber kontra Magyarország és Görögország ügy (75116/01.). 
A Bíróság álláspontja szerint a helyes jogszolgáltatás biztosítása elsődlegesen a PKKB feladata lett volna (ezért Görögországot nem marasztalta el az ügyben), amely egyetlen tárgyalást tartott 1999-ben, s utána 2004-ig nem született ítélet. A PKKB kilenc év alatt mindössze annyit tudott meg, hogy a görög jog tartalma nem állapítható meg. A Bíróság felvetette, hogy a PKKB jogi szakértőt is kirendelhetett volna, ugyanis a régi Kódex 5. § (1) bekezdése ezt lehetővé teszi. Ennek sikertelensége esetén a régi Kódex 5. § (3) bekezdése alapján, kisegítő jogként a magyar jog is alkalmazásra kerülhetett volna, az eljárás felgyorsítására. Mindent egybevetve, a kérelmezők ügyét nem tárgyalták észszerü időn belül, ezért az Egyezmény 6. cikkének (1) bekezdését megsértették, ezért elmarasztalták Magyarországot.

\section{IV.2. Részvények - a német jog tartalmának megállapítása}

A tényállás ${ }^{34}$ szerint a németországi bejegyzésű és székhelyű társaság (felperes) jogellenes részvényátruházás útján megvalósított károkozás megtérítése tárgyában 2009-ben nyújtott be keresetet E. B. magyarországi bejegyzésü és székhelyü pénzintézettel szemben. A felek a kártérítés esedékességére, érvényesítésére a magyar Ptk. rendelkezéseit kötötték ki. A felperes igénye 1998-ban vált esedékessé, de 2000-ben a felperest vagyontalanság okán törölték a német cégjegyzékből. A német bíróság a társaság részére 2001-ban ún. korlátozott hatáskörrel rendelkező utófelszámolót nevezett ki fennálló igénye érvényesítése érdekében, amelyet 2003-ban kiterjesztett az alperessel szemben történő fellépésre is.

A magyar bíróság előtt az alperes vitatta a felperes követelését, a magyar jog szerinti általános elévülési határidő lejártára hivatkozva. A felperes előadása szerint a vagyontalanság miatti törlés miatt nem tudta követelését érvényesíteni, így az elévülés nyugvása az utófelszámoló bejegyzéséig fennállt. A bíróság a Német Szövetségi Igazságügyi Minisztérium német jogról való tájékoztatását is kikérve vizsgálta az utófelszámoló által a bejegyzést megelőzően megtehető jognyilatkozatok körét. Ennek alapján megállapította, hogy az utófelszámoló 2003. augusztus 4-ig az alperessel szembeni fellépésre nem volt jogosult, ennek okán az elévülés nyugvásáról döntött. Hozzátette azonban, hogy az elévülés nyugvását követően csak 2009-ben kívánta igényét érvényesíteni, így a felperes keresetét elutasította.

${ }^{34}$ Kúria Gfv. VII. 30. 248/2015/10. 
A magyar „máltai eset”, cirkuszi artisták, bủvészek és részvények: régi ügyek...

A felperes felülvizsgálati kérelmében kifogásolta, hogy az eljáró bíróságok nem tettek eleget a Kódex 5. § (1) bekezdésében foglalt kötelezettségüknek. Álláspontja szerint a per folyamán a felek között a Német Szövetségi Igazságügyi Minisztérium német jogról történő tájékoztatásának pontos tartalma végig vitatott volt, amely ellentmondásokat a magyar bíróságok - pl. szakértő kirendelésével - nem oldottak fel. A felperes érvelése szerint a német jog alapján az utófelszámoló a 2003. augusztus 4-i bejegyzéséig terjedő időszakban is tehetett - és tett - az elévülési időt meghoszszabbító nyilatkozatokat, ebből kifolyólag a követelés nem évült el. A német jog téves alkalmazása miatt állapította meg a bíróság helytelenül az utófelszámoló képviseleti jogának terjedelmét, így az elévülés nyugvását.

A Kúria döntésében rámutatott, hogy a bíróság hivatalból szerezte be a német jogról szóló tájékoztatást. Kiemelte, hogy nem szükséges szakértő igénybevétele, ha a külföldi jog tartalma a rendelkezésre álló tájékoztatás alapján kellő bizonyossággal megállapítható. Mivel a bíróságnak a felek által készített fordítás megbízhatóságával kapcsolatban észszerủ kétsége nem merült fel, további eszközök igénybevételére nem volt szükség, ennek megfelelően az alsóbb fokú bíróság döntését hatályában fenntartotta.

IV.3. Az esetek elemzése

A külföldi jog alkalmazása egyre növekvő százalékban jelenik meg, ti. napjaink felgyorsult és mobil világában a megítélendő jogviták egyre nagyobb része már nem a fórum joga szerint kerül elbírálásra. Ez rendkívüli terhet ró a jogalkalmazóra, mert a külföldi jog alkalmazása időigényes, költséges és magában hordozza a téves döntések kockázatát. Nem véletlen, hogy a külföldi jog alkalmazását a „kollíziós nemzetközi magánjog keresztjének" is nevezik. ${ }^{35}$

A nemzetközi magánjogi kodifikációk fontos pontja, hogy hogyan szabályozzák a külföldi jog alkalmazásának kérdését. ${ }^{36} \mathrm{~A}$ régi Kódex 5. § (1) bekezdése deklarálta, hogy a „bíróság vagy más hatóság az általa nem ismert külföldi jog felől hivatalból tájékozódik", azaz ebből levezethető volt, hogy a hazai fórum ex offico kell alkalmazza a külföldi jogot.

Az új Kódex már ketté választja a külföldi jog alkalmazásának és tartalma megállapításának területét, és kifejezetten deklarálja: „,7. § (1) A bíróság a külföldi jogot

35 Fentiman [1998], 1. o.

${ }^{36}$ Lásd még a témáról pl.: Bóka [2014], 23-33. o.; Burián-Szabó [2017]; Harsági-Kengyel-Nemessányi [2011]. 
hivatalból alkalmazza.” Tekintettel arra, hogy a külföldi jog helyes alkalmazásához ráadásul ismerni kell annak jogalkalmazási gyakorlatát is, a (2) bekezdésben rögzíti: „A bíróság a külföldi jogot annak saját szabályai és gyakorlata szerint értelmezi”.

A külföldi jog tartalmának megállapítása tekintetében a régi Kódex szövegében: amennyiben a bíró maga nem ismeri a külföldi jog tartalmát, „szükség esetén szakértői véleményt is beszerez és a fél által előterjesztett bizonyítékokat is figyelembe veheti” (Kódex 5. § (1) bekezdés). Egy további lehetőségként rögzítette, hogy a fórum megkeresésére a külföldi jogról az igazságügyért felelős miniszter ad felvilágosítást (Kódex 5 . $\S(2)$ bekezdés). Ez a megfogalmazás a gyakorlatban több esetben félrevezető volt, mint azt a részvényekkel kapcsolatos esetben láttuk. Egyértelmü, hogy a bírónak a külföldi jog tartalmának bizonyítását illetően szabad mozgástere van, ugyanis a föszabály, hogy a bíróságnak nem kell a külföldi jog tartalma felől tájékozódni, amennyiben azt ismeri. ${ }^{37}$ Továbbá, helyesen állapította meg a Kúria elődje, hogy az 5.§ (1) bekezdése lehetőséget ad arra, hogy az alkalmazandó jog tekintetében a bíróság a fél által előterjesztett bizonyítékot is figyelembe vegye, és kimondta, hogy erre tekintettel fel lehet kérni a felet a vonatkozó külföldi jog bizonyítására. ${ }^{38}$ Mindazonáltal, ha a felek e felöl önként nem intézkednek, a bíróság feladata a külföldi jog tartalmának megállapítása. A korábbi szöveg azt sugallta, hogy az Igazságügyi Minisztérium minden esetben felvilágosítást ad a külföldi jogról, de sok esetben, különösen akkor, ha nincs az adott országgal nemzetközi egyezmény, ${ }^{39}$ ez nem lehetséges, avagy ha van is fennálló nemzetközi megállapodás, az ez alapján történő megkeresés jelentős időt vehet igénybe (ráadásul a szöveget a fórumnak adott esetben - még le is kell fordíttatni). Az új Kódex szerint: „8. § (1) A külföldi jog tartalmát a bíróság hivatalból állapítja meg. (2) A külföldi jog tartalmának megállapitásához a bíróság bármely eszközt igénybe vehet, igy különösen a felek elöterjesztéseit, szakvéleményt vagy az igazságügyért felelös miniszter (a továbbiakban: a miniszter) erre vonatkozó tájékoztatását." A korábbi megfogalmazáshoz képest a szöveg egyértelmüsíti a jogalkalmazó számára, hogy amennyiben a bíró nem ismeri az adott külföldi jog megfelelő tartalmát, akkor a felek előterjesztése, szakvélemény és a miniszter tájékoztatása egyaránt figyelembe vehető. Nem csak utóbbira célszerü tehát hagyatkozni, ahogy ezt az Emberi Jogok Európai Bírósága a fentebb ismertetett ítéletében is hangsúlyozta.

37 Fővárosi Ítélőtábla Pf.6.20.666/2003/3.

38 BH1981.255.

${ }^{39}$ Bilaterális egyezmények, vagy az ún. Londoni Egyezmény [európai egyezmény a külföldi jogról való tájékoztatásról (1968) és kiegészítő jegyzőkönyve (Strasbourg; 1978)] alapján. 
A magyar „máltai eset”, cirkuszi artisták, bủvészek és részvények: régi ügyek...

Az új Kódex (3) bekezdés első mondata is az az Emberi Jogok Európai Bírósága gyakorlatának következménye (hazánk vonatkozásában a tárgyalt Karalyos és Huber ügy), amely számos más ország kodifikációjában is megjelenik. Eszerint: „Ha a külföldi jog tartalma észszerü időn belül nem állapitható meg, akkor a magyar jogot kell alkalmazni.” Az észszerủ időn belüliség kritérium kifejezetten megjelenik pl. a belga, a cseh, az észt, a lengyel, az osztrák ${ }^{40}$ jogban. Másutt a bírói gyakorlat jár el így (finn, német, svéd). ${ }^{41}$ Az ún. Madridi Alapelvek is támogatja ennek kodifikálását: „Ha a fórum meglátása szerint a) a külföldi jog tartalmának megállapítása észszerű időn belül nem lehetséges, vagy b) a külföldi jog az adott kérdés eldöntésére nem alkalmas, akkor a lex fori kerül alkalmazásra." (9. alapelv). ${ }^{42}$

Bár a lex fori alkalmazásának mint kisegítő jognak praktikus okai vannak. Mégis elképzelhető olyan eset, hogy a magyar jog szabályai nem hoznak eredményt (mert mondjuk az adott jogkérdést a hazai jog nem ismeri, az a magyar jog alapján nem megfelelően rendezhetö), ilyen ritka és kivételes helyzetekben az a helyes, ha a fórum a külföldi jog mellőzésének ezen eseteiben ne automatikusan a saját jogát, hanem az eredetileg alkalmazandó joghoz a lehető legközelebb álló jogot „találja meg”. Egyik ilyen alternatív megoldás, egy harmadik - az alkalmazandó joghoz szorosan kapcsolódó (neighbour law, droit voisin) - jogrendszer helyettesítő szabályának alkalmazása. Pl. az angol jog szabályai helyettesíthetik az új-zélandiét. ${ }^{43}$ Az új Kódex (3) bekezdés második mondata ennek megfelelően akként rendelkezik, hogy ,,[h]a a magyar jog szabályai alapján az adott tényállás nem bírálható el, akkor az alkalmazandó joghoz legközelebb álló külföldi jogot kell alkalmazni”. Természetesen ezzel az eszközzel igazán kivételes esetben célszerü élni, hiszen nem szabad, hogy emiatt az eljárások további elhúzódása történjen. ${ }^{44}$

\section{V. Összegzés}

A fentebb bemutatott esetekből és elemzésükből látható, hogy a nemzetközi magánjogi kérdések megítélése korántsem egyszerü feladat. Azonban az új Kódex

${ }^{40}$ OGH értelmezésében: ennek célja, hogy bizonyos körülmények esetén megállítsa a külföldi jog tartalmának keresését (1994.01.26.). Bővebben: Szabó [2016], 78. o.

${ }^{41}$ Uo.

${ }^{42}$ Részletesen: Esplugues Mota [2011], 273-297. o. Magyar fordítás és megjegyzések a kodifikáció kapcsán: Szabó [2016], 60-83. o.

${ }^{43}$ Pl.: Bogdan [2012], 165. o.; Basedow [2014], 95-96. o.

${ }^{44}$ Szabó [2016], 60-83. o., különösen 83. 
alapján, a jövőbeli hasonló ügyek elbírálása során a jogalkalmazók több eszközzel élhetnek a nemzetközi magánjogi jogelvek érvényesülésének garantálása érdekében, amely az eljáró fórumok számára a régi Kódexnél nagyobb rugalmasságot biztosíthat. Ám ennek érdekében a jogalkotónak is szükséges lenne az általános részt illetően az általános kitérítő klauzula használhatóvá tétele felöl intézkednie akként, hogy a nemzetközi összehasonlításban is unikumnak számító korlátozást a modernitás igényével megalkotott új Kódex szövegéből törli.

\section{Irodalomjegyzék}

Basedow, Jürgen [2014]: The Application of Foreign Law - Comparative Remarks on the Practical Side of Private International Law. Max Planck Private Law Research Paper, No. 17.

Bogdan, Michael [2012]: PIL as Component of a Law of a Forum. Brill Nijhoff, Hague

Bóka János [2014]: Jogharmonizációs dilemmák a külföldi jog tartalmának megállapításával kapcsolatban. Iustuum Aequum Salutare, 2. sz.

Burián László [2017]: Általános részi jogintézmények szabályozása a régi és az új nemzetközi magánjogi Kódexben. Budapest, Kézirat [Megjelenik: Közjegyzők Közlönye 2018. júniusi szám].

Burián László [2016]: A vissza- és továbbutalás (renvoi). In: Berke-Nemessányi (szerk.): Az új nemzetközi magánjogi törvény alapjai. Budapest, HVG-ORAC.

Burián László - Czigler Dezső Tamás - Kecskés László - Vörös Imre [2010]: Európai és magyar nemzetközi kollíziós magánjog. Budapest, Krim Bt.

Burián László - Raffai Katalin - Szabó Sarolta [2017]: Nemzetközi magánjog. Budapest, Pázmány Press.

Burián, László - Szabó, Sarolta [2017]: Inconsistencies between Theory and Practice in the Treatment of Foreign Law in Hungary. In: Treatment of Foreign Law: Dynamics towards Convergence, Nishitani, Yuko (Ed.), Ius Comparatum - Global Studies in Comparative Law, Vol. 26. Springer, Cham.

Esplugues Mota, Carlos [2011]: Application of Foreign Law. Harmonization of Private International Law in Europe and Application of Foreign Law: the „Madrid Principles” of 2010. In: Yearbook of Private International Law, Vol. 13., Sellie.

Fentiman, Richard [1998]: Foreign Law in English Courts. Pleading, Proof and Choice of Law. OUP, Oxford

Harsági, Viktória - Kengyel, Miklós - Nemessányi, Zoltán [2011]: Hungary. In: Application of Foreign Law, C. Esplugues - J. L. Iglesias - Guillermo Palao (eds.), Sellier.

Mádl, Ferenc [1987]: Values versus legal security in private international law. Acta Juridica Academiae Scientiarum Hungaricae, Vol. 29., 3-4. sz.

Mádl Ferenc [1980]: Magyarország első nemzetközi magánjogi törvénykönyvéröl. Állam- és Jogtudomány, 2. sz.

Mádl Ferenc - Vékás Lajos [2012]: A nemzetközi magánjog és nemzetközi gazdasági kapcsolatok joga. ELTE Eötvös Kiadó, Budapest

Nagy Csongor István [2017]: Nemzetközi magánjog. Budapest, HVG-ORAC

Raffai Katalin [2017]: A magyar nemzetközi magánjog megújulása - néhány észrevétel a nemzetközi magánjogi törvény újrakodifikálásáról, különös tekintettel a törvény általános részére. Külgazdaság Jogi Melléklet, 61. évf., 5-6. sz. 
Szabó Sarolta [2016]: A külföldi jog alkalmazásának (tartalma megállapításának) problematikája. In: Berke-Nemessányi (szerk.): Az új nemzetközi magánjogi törvény alapjai. Budapest, HVG-ORAC Szabó Sarolta (föszerk.) - Raffai Katalin - Vadász Vanda (szerk.) [2017]: Nemzetközi magánjog jogszabály- és jogesetgyüjtemény. Pázmány Press, Budapest.

Vékás Lajos [2016]: A törvény szerkezetéről és néhány általános részi kérdésről. In: Berke-Nemessányi (szerk.): Az új nemzetközi magánjogi törvény alapjai. Budapest, HVG-ORAC.

Vékás Lajos [2015]: Egy új nemzetközi magánjogi törvény megalkotásának néhány elvi kérdéséről. Jogtudományi Közlöny, LXX. évf., 6. sz.

Vékás Lajos [1986]: A nemzetközi magánjog elméleti alapjai. Tankönyvkiadó, Budapest, kézirat. 